\title{
Holocene Vegetation and Climate inferences from Phytoliths and Pollen from Lagoa do Macuco, North Coast of Espírito Santo State (Brazil)
}

\author{
Inferências sobre Vegetação e Clima no Holoceno a partir de Fitólitos e \\ Pólen da Lagoa do Macuco, Litoral Norte do Estado do Espírito Santo \\ (Brasil)
}

\section{${ }^{\text {ae }}$ Marcia Regina Calegari, ${ }^{\text {bf }}$ Marco Madella, ${ }^{\text {cg }}$ Antonio Alvaro Buso Jr, ${ }^{\text {dh }}$ Margaritha L Osterrieth, ${ }^{\text {ci }}$ Flávio Lima Lorente, ${ }^{\mathrm{cj}}$ Luiz Carlos R. Pessenda}

\author{
${ }^{a}$ Colegiado de Geografia , Universidade Estadual do Oeste do Paraná - UNIOESTE - Campus Marechal Cândido Rondon, ${ }^{\text {ICREA - }}$ \\ Complexity and Socio-Ecological Dynamics (CaSEs), Department of Humanities Universitat Pompeu Fabra - IMF Consejo Superior \\ de Investigación Cientifica (CSIC), ${ }^{\mathrm{C}}$ Laboratório de Carbono-14, CENA/USP, ${ }^{\mathrm{d}}$ Centro de Geología de Costas y del Cuaternario \\ FCEyN, Universidad Nacional de Mar del Plata \\ emarciareg_calegari@hotmail.com, ${ }^{\mathrm{f}}$ marco.madella@icrea.cat, ${ }^{\mathrm{g}}$ aabuso@ cena.usp.br, ${ }^{\mathrm{h}}$ mosterrii@ $\mathrm{hotmail.com}$, \\ iflimalorente@yahoo.com.br, ${ }^{j}$ pessenda@cena.usp.br
}

\begin{abstract}
Resumo
Uma abordagem interproxy focada na análise de fitólitos e de grãos de pólen, também incluindo datação ${ }^{14} \mathrm{C}$ e análise granulométrica de sedimentos, foi aplicada ao estudo da Lagoa do Macuco, em Linhares no Estado do Espírito Santo. Foram identificadas três zonas polínicas definidas com base nas mudanças do registro polínico, a primeira (MAC-C I) indicando a presença de uma vegetação de mangue entre 7700 anos cal AP e 4396 anos cal AP, a segunda (MAC-C II) que representa o deslocamento da vegetação das áreas mais baixas para as partes marginais mais elevadas do vale (4396 anos cal AP - 1287 anos cal AP) e a terceira (MAC-C III) que representa o período da instalação do atual lago, entre 1287 anos cal AP e os dias atuais. O deslocamento do mangue parece estar conectado a migração em direção ao paleo-estuário e o alagamento das partes baixas do vale, refletindo a elevação do nível relativo do mar depois de $7000 \mathrm{cal}$ anos AP. A análise fitolítica indicou quatro zonas principais. A zona fitolítica I (7700-7100 anos cal AP), não apresentou fitólitos. A zona fitolítica II (7100-3400 anos cal AP) indica a presença de uma vegetação predominantemente composta por gramíneas, enquanto a zona fitolítica III (3400-400 anos cal AP) mostrou uma fase com uma vegetação mais florestada. Finalmente, a zona fitolítica IV, (400 anos cal AP até os dias atuais) apresentou decréscimo da cobertura arbórea e uma estrutura de vegetação com forte presença de gramíneas em sua composição. Os índices fitolíticos indicaram tendência de umidade e temperatura em escala local permitindo a compreensão das condições ambientais durante a formação do lago atual
\end{abstract}

Palavras-chave: opala biogênica; pólen; índices fitolíticos; vegetação; Holoceno

\begin{abstract}
An interproxy approach focused on phytoliths and pollen, including radiocarbon dating and sediment particle-size analyses, has been carried out at Lagoa do Macuco, Linhares municipality, Espírito Santo State, Brazil. Three pollen zones were identified: the first one (MAC-C I) indicates the presence of mangrove vegetation between $7700 \mathrm{cal} \mathrm{yr} \mathrm{BP}$ and $4396 \mathrm{cal} \mathrm{yr} \mathrm{BP}$; the second one a displacement of the vegetation from the lower areas to the more elevated margins of the valley (MAC-C II, from between 4396 to $1287 \mathrm{cal}$. yr BP) and third one (MAC-C III), representing the period of the current lake evolution, between $1287 \mathrm{cal}$. yr BP and the present day. The displacement of the mangrove seems to be connected to the landward migration of the palaeo-estuary and the flooding of the lower parts of the valley, reflecting the relative sea-level highstand, which occurred after $7000 \mathrm{cal} \mathrm{yr}$ BP. The phytolith analysis indicated four main zone. The phytolith zone I (7700-7100 cal yr BP) did not show the presence of phytoliths. The phytoliths zone II (7100-3400 cal yr BP) indicates the presence of an open vegetation predominantly of grasses while phytolith zone III (3400-400 cal yr BP) shows a phase with more forested vegetation. Finally, the phytolith zone IV (400 cal yr BP to modern) has a decrease in tree cover and the setting of vegetation with a strong grasses component. Phytoliths indices indicate trends of humidity and temperature at a more local scale, allowing understanding the environmental conditions during the formation of the current lake.
\end{abstract}

Key-words: biogenic opal; pollen, phytoliths índices; vegetation; Holocene 


\section{Introduction}

The use of interproxies (biotic and abiotic) strategy strongly enhances the study of past environments (e.g. Curtis et al. 1998, Birks \& Birks 2006, Buso Jr. et al. 2013) since they provide distinct complementary information, reinforcing and extending our interpretative power. The combination of two (strong) vegetation proxies, such as pollen and phytoliths, increases the capability of gathering information about regional and local past vegetation communities, reflecting species migration and ecological successions after disturbances, environmental change, and global climatic changes.

In the Neotropic pollen analysis has already being proved to be an important proxy from waterlogged sediments while phytoliths were successfully used in both waterlogged and terrestrial deposits (e.g. Bartlett \& Barghoorn 1973, Piperno 1993, Alexandre et al. 1997b, Mworia-Maitima 1997, Piperno \& Pearsall 1998, Piperno \& Jones 2003, Thorn 2004, Penny \& Kealhofer 2005, Piperno 2006). In Brazil, there are surprisingly few works focusing on phytolith (Kondo \& Iwasa 1981, Alexandre \& Meunier 1999, BorbaRoschel et al. 2006, Calegari et al. 2013a, Coe et al. 2013) and none in which pollen and phytoliths have been analysed together.

The objective of the present study was to exploit/use the combined potential of opal phytoliths and pollen from the lagoon sediments of Macuco to understand the Holocene vegetation history and palaeoclimatic conditions in a coastal Mata Atlântica forest (Ombrophylous Dense Forest).

\section{Regional setting}

Lagoa do Macuco $\left(19^{\circ} 02.584^{\prime} \mathrm{S} / 39^{\circ} 56.695^{\prime} \mathrm{W}\right)$ is a freshwater lake in the lower course of Barra Seca River (figure 1). The lake is set in an incised valley $23 \mathrm{Km}$ from the sea, along the southeastern coast of Brazil. The valley cuts the Barreiras Formation, a sedimentary domain composed by sandstones, conglomerates and mudstones mainly of Neogene fluvial and alluvial fan deposits with possible inclusions from coastal onlaps associated with Neogene marine transgressions (Arai 2006, Dominguez 2009).

The vegetation developed on the Barreiras Formation is largely composed by the Mata Atlantica tropical rainforest. The most representative plant families of this biome are Fabaceae, Myrtaceae, Sapotaceae, Bignoniaceae, Lauraceae, Hippocrateaceae, Euphorbiaceae, Annonaceae and Apocynaceae (Peixoto \& Gentry 1990). The vegetation of the lake and its surroundings comprises trees such as Tabebuia cassinoides (Lam.) DC., Alchornea triplinervia (Spreng.) Müll.Arg. and Cecropia sp., and herbaceous plants from the Cyperaceae, Poaceae (e.g. Typha sp.) and Pteridophytae as well as floating and submerged flora such as Salvinia sp., Cabomba sp., Utricularia sp., Tonina sp. A freshwater marsh with herbaceous vegetation develops on the lowlands of the Barra Seca Valley.

At the time of coring, the water column in the deepest part of Lagoa do Macuco was ca. $3 \mathrm{~m}$ and the altitude at the water surface was $1 \mathrm{~m}$ above sea level (a.s.1.).

\section{Material and methods}

A piston corer (Livingstone 1955) was used to collect a $204 \mathrm{~cm}$ sediment core (MAC-C) at the center of the freshwater lake Lagoa do Macuco. The core tube was opened longitudinally in two halves and samples collected at $2 \mathrm{~cm}$ intervals in the ${ }^{14} \mathrm{C}$ Laboratory (CENA/USP).

\subsection{Sediments description and granulometry}

The sediment core was described based on its colours and macroscopic characteristics. Particle-size determination was carried out in 71 samples, pretreated with hydrogen peroxide $(10 \%)$ for organic matter removal and ultrasonically dispersed before laser diffraction analysis in a Laser Particle Size Shimadzu Sald 3101. Results of particle-size distribution are presented according to the Wentworth (1922) scale.

\subsection{Radiocarbon age}

Sixteen samples were selected for ${ }^{14} \mathrm{C}$ dating. Samples were treated with $2 \%$ to $4 \%$ hydrochloric acid at $60^{\circ} \mathrm{C}$ during four hours, washed and dried at $50^{\circ} \mathrm{C}$ (Pessenda et al., 2009; Buso Jr. et al. 2013). After combustion, the $\mathrm{CO}_{2}$ was used for AMS dating. Ages are expressed in years before present (yr BP) and

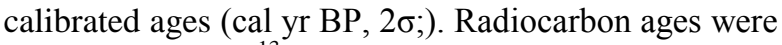
normalized to a $\delta^{13} \mathrm{C}$ of $-25 \%$ VPDB and reported as calibrated years (cal yr BP, $2 \sigma$ ) according to Reimer et al. (2004). For post-bomb sample the ${ }^{14} \mathrm{C}$ activity is provided as the percentage of modern carbon (pMC) and calibrated age in cal $\mathrm{AD}$, according to the CALIBomb software (McCormac et al. 2004). Calibrated ages were used for the construction of an age-model in the Tilia software $\mathrm{v} 1.7 .16$ (Grimm 1992), using a B-spline approximation model, which is used for age interpolation of any undated sample.

\subsection{Pollen analysis}

For pollen analysis, 26 samples of $1 \mathrm{~cm}^{3}$ were processed according to Colinvaux et al. (1999), with the addition of exotic Lycopodium spores to determine pollen and spores concentrations (grains $/ \mathrm{cm}^{3}$ ) and accumulation rates (grains $\mathrm{cm}^{-2} \mathrm{yr}^{-1}$ ) as per Davis \& Deevey (1964). Percentages of pollen and spores were calculated based on the total pollen sum, which includes all pollen types and indeterminates.

For each sample, pollen and spores were counted until reaching a minimum of 300 arboreal pollen grains (mangrove included). The identification was based on published pollen morphology and on the pollen reference collection of the ${ }^{14} \mathrm{C}$ Laboratory (CENA/USP). Identified types were grouped into 
mangrove trees, other trees/shrubs, aquatics, herbs, and terrestrial ferns. Indeterminate pollen includes unidentified and reworked grains. CONISS (Grimm
1987) was used to run a cluster analysis based on pollen and spore counts from all taxa.

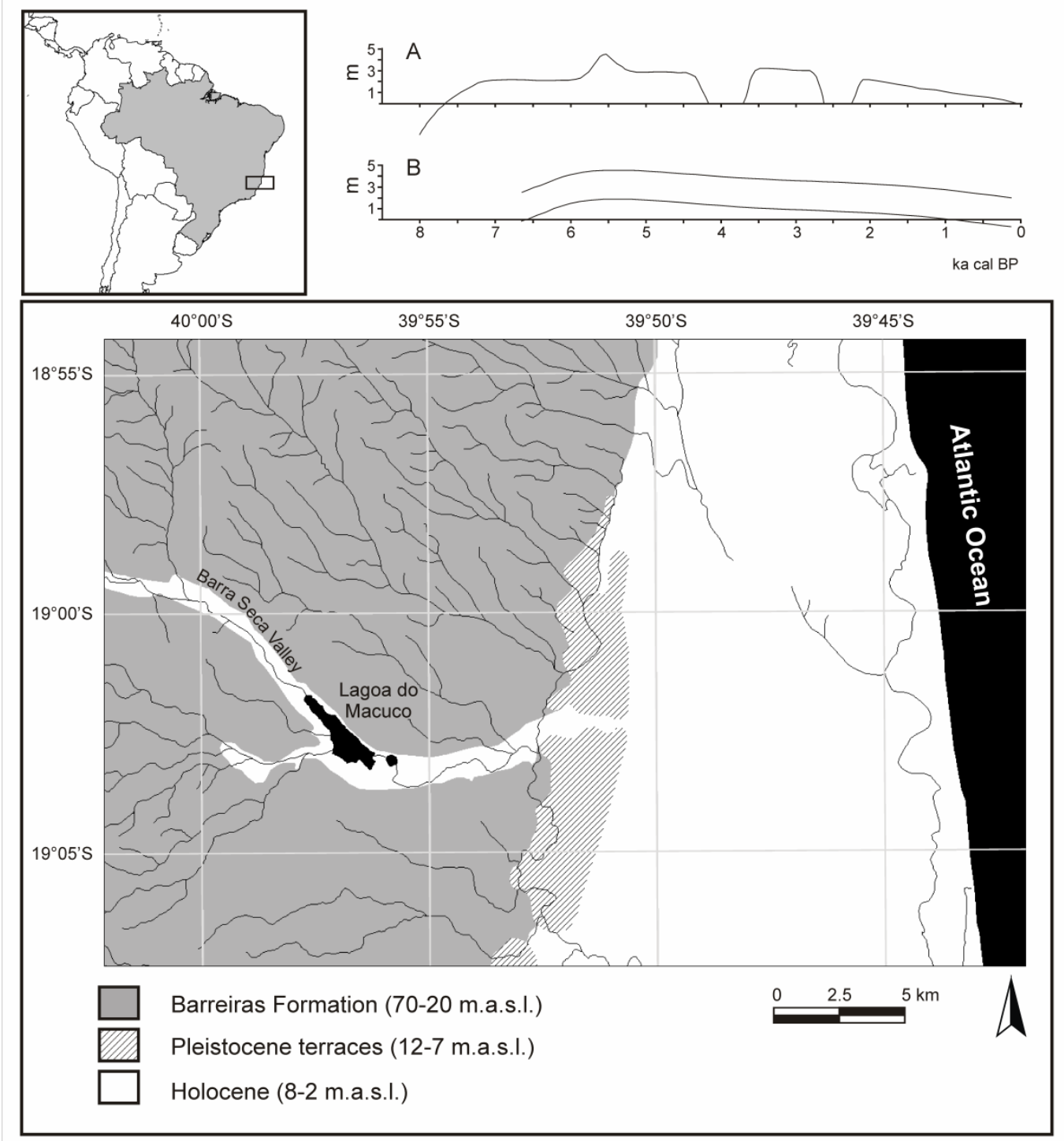

Figure 1: Study site. Map showing the location of the study site at the Brazilian coast (upper left panel), and in the geologic and elevation contexts (lower panel); relative sea-level curves for the southeastern Brazilian coast (upper right panel), in meter above present sea-level (m.a.s.1.), versus the time in thousands of calibrated years (ka cal BP); (A) subpanel from Martin et al. (2003); (B) subpanel from Angulo et al. (2006).

\subsection{Phytolith sampling and extraction}

The phytolith samples were taken in parallel to the pollen samples down to a depth of $194 \mathrm{~cm}$. Phytoliths were extracted from twenty-three samples of $1 \mathrm{~cm}^{3}$, but only fifteen of these samples contained phytholits. The average weight of dry sediment was 0,50 grams with 0,15 standard deviation. Extraction followed Madella et al. (1998) and Calegari et al (2013b), consisting in the removal of carbonates and iron oxide and/or aluminum by hydrolysis with strong acid $(\mathrm{HCl}-5 \mathrm{~N})$ followed by oxidation with $\mathrm{H}_{2} \mathrm{O}_{2}$ (30\%) for the removal of the SOM. The concentration and separation of phytoliths was done gravimetrically, using a solution of sodium polytungstate $\left(\mathrm{Na}_{6}\left(\mathrm{H}_{2} \mathrm{~W}_{12} \mathrm{O}_{40}\right) \mathrm{H}_{2} \mathrm{O}\right)$ with density of $2.35 \mathrm{~g} \mathrm{~cm}^{-3}$ (Madella et al. 1998, Osterrieth et al. 2009).

\subsection{Classification and counting of phytoliths}

Each microscopy slide was prepared with immersion oil and phytoliths were observed across three horizontal transects (Carnelli 2002): top, middle and bottom. Observations were carried out with a Condo microscope at 400x magnification. The identified morphotypes were named according to the International Code for Phytolith Nomenclature (Madella et al. 2005). Phytoliths were combined into five major groups according to their taxonomic origin: Poaceae (grasses) (Twiss et al. 1969, Tieszen et al. 1979, Twiss 1992), Arecaceae (palms) (Kondo \& Iwasa 1981, Piperno 2006, Alexander et al. 1997b, 1999, Barboni et al. 1999), Cyperaceae (sedges), Maranthaceae (Piperno, 2006) and Eudicotiledoneae (mostly woody dicots) (Runge 1999). 
From the assemblages, three palaeoenvironmental phytolith indices were calculated:

- The Humidity-Aridity Index (Iph) (Diester-Haas et al. 1973, Alexandre et al. 1997b), which is based on the ratio of chloridoid versus chloridoid and panicoid phytoliths. High Iph values suggest open woodlands and/or grasslands dominated by xerophytic Chloridoideae, indicating dry edaphic and/or climatic conditions. Low Iph values indicate the predominance of mesophytic Panicoideae, suggesting more humid conditions.

- The Climatic Index (Ic) (Twiss 1987, 1992) is the ratio of pooid versus the sum of pooid, chloridoid and panicoid morphotypes. High values indicate the predominance of C3 Pooideae grasses, suggesting cold climatic conditions.

- The Tree Cover Density Index (D/P) (Alexandre et al. 1997b, 1999, Barboni et al. 1999, 2007) consists of the $\mathrm{D} / \mathrm{P}$ ratio, where $\mathrm{D}$ is the number of dicotyledon phytoliths (globular morphotypes) and $\mathrm{P}$ is the number of Poaceae phytoliths (pooids, chloridoids, panicoids, trichomes and bulliforms). High values indicate open vegetation, adapted to warm and dry climates, as in the African tropical and intertropical zones; lower values indicate forest vegetation with warm and wet climates

\section{Results and discussion}

\subsection{Sediments description and granulometry}

The MAC-C core consists of 5 sedimentary intervals. From 204 to $200 \mathrm{~cm}$ the sediment is dark green silt, abruptly changing to dark greenish-gray laminations of sand and silt, from 200 to $144 \mathrm{~cm}$. From 144 to $78 \mathrm{~cm}$ the sediment gradually changes to a massive light gray mud, with predominance of silt and clay. In the zone between 78 to $70 \mathrm{~cm}$ the sediment grades to dark gray silt with transitional contacts. The uppermost $70 \mathrm{~cm}$ is a black gyttja with sand and silt.

\subsection{Radiocarbon age estimation}

The AMS ${ }^{14} \mathrm{C}$ dates range from $7667-7430 \mathrm{cal}$ yr BP near the base of the core to cal AD 1958-1996 at the top (table 1). These dates can be considered reliable because:

- The date obtained at $198-200 \mathrm{~cm}$ is from terrestrial plant fragments;

- All samples were pre-treated for carbonate removal;

- Lake reservoir effect, hard water effect, or the assimilation of some other form of old carbon are probably negligible, considering the modern age obtained from sample $4-6 \mathrm{~cm}$ (which is the expected age for this depth);

- The dates are all in stratigraphic order and no inversion is evident.

\subsection{Pollen record}

Pollen and spores diagrams of percentages and accumulation rates for MAC-C core are shown in figure 2. Pollen and spores concentrations ranged from ca. 11,000 grains per $\mathrm{cm}^{3}(76 \mathrm{~cm})$ to more than 200,000 grains per $\mathrm{cm}^{3}(68 \mathrm{~cm})$. Three pollen zones have been defined from the cluster analysis.

Pollen Zone MAC-I from 7623 to 4396 cal yr BP (204 to $96 \mathrm{~cm}$ ). Pollen accumulation rates are relatively low in this pollen zone (475-2316 grains. $\left.\mathrm{cm}^{-2} / \mathrm{yr}^{-1}\right)$. The interval is characterized by high percentages and accumulation rates of pollen grains from mangroves (23-53\%) and other trees and shrubs (20-46\%). In the first part of this pollen zone (from 204 to $150 \mathrm{~cm}$ ) the input of herbaceous (6-9\%) and aquatic (0-1\%) pollen grains and spores (3-7\%) is very low. From 150 to 96 $\mathrm{cm}$ herbaceous (11-25\%) and aquatic (0-2\%) pollen grains and spores (12-23\%) present higher percentages (figure 2).

Higher percentages of Cyatheaceae spores are found from 144 to $96 \mathrm{~cm}$, which justifies the delimitation of the sub-zone MAC-Ib dated at 7085-4396 cal yr BP (see Buso Jr. et al. 2013b). In Brazil, Cyatheaceae is represented by tree ferns that usually colonize humid forests (Lorscheitter et al. 1999) and according to Marchant et al. (2002) these spores should be indicative of humid environmental conditions. This higher humidity could be a consequence of a higher water table connected to the estuarine movements. Although the vegetation dynamics inside Barra Seca Valley may have been primarily a response to relative sea-level changes, further investigations are necessary to clarify these dynamics connected to possible climatic fluctuations during the period from 7000 to 4300 cal yr BP (Buso Jr. et al. 2013b).

Pollen Zone MAC-II from 4396 to 1287 cal yr BP (96 to $72 \mathrm{~cm}$ ). Pollen accumulation rates (41-1247 grains $\mathrm{cm}^{-2} \mathrm{yr}^{-1}$ ) are lower than pollen zone MAC-I. During this interval mangrove pollen grains are rare or absent $(0-8 \%)$. The majority of the retrieved pollen is represented by herbaceous $(25-50 \%)$ and trees/shrubs pollen (30-70\%), nonetheless aquatics (4-11\%) and spores $(4-21 \%)$ have significant frequencies.

Changes in the accumulation rates of mangrove pollen and associated proxies ( $\mathrm{C}$ and $\mathrm{N}$ isotopes, chemical analyses, siliceous sponge spicules) in Macuco sequence have been related to fluctuations of Holocene relative sea-level of the Brazilian coast (Buso Jr. et al. 2013b). At the beginning of Pollen Zone MAC-I (ca. 7700 cal yr BP) arboreal and dense mangrove vegetation would have occupied the lower reaches of Barra Seca Valley. From ca. 7000 to 3200 cal $\mathrm{yr} \mathrm{BP}(144$ to $80 \mathrm{~cm})$ the reduction of pollen accumulation rates (figure 2) should represent the displacement of the vegetation to the higher reaches of the valley due to the landward migration of the palaeoestuary and the sea flooding of the lower parts of the valley (Martin et al. 2003, Angulo et al. 2006, MurrayWallace 2007). This process is not reflected in the pollen diagram (figure 2A), however it is evident in the 
Estudos ambientais sobre a vegetação e o clima no Holoceno

carbon and nitrogen stable isotopes signatures as well as the sponge spicules record (Buso Jr. et al. 2013a).

Table 1: ${ }^{14} \mathrm{C}$ results of the core MAC-C from Lagoa do Macuco

\begin{tabular}{|c|c|c|c|c|}
\hline Laboratory \# & Dated material & Depth (cm) & Age (BP) & Age (cal yr BP; 2б) \\
\hline UGAMS3405 & Bulk sediment & $4-6$ & $101.39 \pm 0.33 *$ & $1,958-1,996^{* *}$ \\
\hline UGAMS3406 & Bulk sediment & $20-22$ & $100 \pm 30$ & $253-0$ \\
\hline UGAMS3407 & Bulk sediment & $48-50$ & $110 \pm 30$ & 253-0 \\
\hline UGAMS4265 & Bulk sediment & $64-66$ & $290 \pm 25$ & $440-154$ \\
\hline TO13702 & Bulk sediment & $68-70$ & $1,090 \pm 90$ & $1,171-767$ \\
\hline UGAMS3408 & Bulk sediment & $72-74$ & $1,430 \pm 30$ & $1,348-1,190$ \\
\hline TO13483 & Bulk sediment & $76-78$ & $2,440 \pm 70$ & $2,717-2,208$ \\
\hline UGAMS4266 & Bulk sediment & $80-82$ & $3,260 \pm 25$ & $3,479-3,361$ \\
\hline UGAMS4267 & Bulk sediment & $92-94$ & $3,820 \pm 25$ & $4,238-3,992$ \\
\hline TO13699 & Bulk sediment & $108-110$ & $4,560 \pm 60$ & $5,431-4,888$ \\
\hline TO13700 & Bulk sediment & $122-124$ & $4,580 \pm 120$ & $5,571-4,858$ \\
\hline UGAMS4268 & Bulk sediment & $126-128$ & $5,460 \pm 30$ & $6,293-6,024$ \\
\hline UGAMS4269 & Bulk sediment & $134-136$ & $5,780 \pm 30$ & $6,634-6,414$ \\
\hline TO13484 & Bulk sediment & $138-140$ & $6,100 \pm 80$ & $7,159-6,694$ \\
\hline TO13701 & Bulk sediment & $170-172$ & $6,470 \pm 70$ & $7,458-7,172$ \\
\hline TO13485 & Plant fragments & $198-200$ & $6,730 \pm 80$ & $7,667-7,430$ \\
\hline
\end{tabular}

From 3190 to $1287 \mathrm{cal}$ yr BP $(80$ to $72 \mathrm{~cm}$ ) the increase of the accumulation rates of pollen and spores and the high percentage of herbaceous pollen grains (figure 2) are interpreted as the colonization of the area by pioneer vegetation due to marine regression (Buso Jr. et al. 2013a, b). Although during this interval the pollen record of the core shows increasing concentration of Poaceae (23\%), carbon isotopes analysis indicates C3 plants as the most important origin of the organic matter (Buso Jr. et al. 2013b).

Pollen Zone MAC-III, $1287 \mathrm{cal}$ yr BP to the present (70 $\mathrm{cm}$ to the top of the core). This interval has the highest pollen accumulation rates of the entire deposit (978-37,064 grains $\mathrm{cm}^{-2} \mathrm{yr}^{-1}$ ). Mangrove pollen is not present in this pollen zone and herbs (31-69\%) and trees/shrubs (25-43\%) dominated the interval. Herbaceous pollen grains are mainly Poaceae (16-29\%) at the beginning and then Cyperaceae (25-62\%) in the uppermost samples. At the same time, pollen from aquatic plants increases reaching the value of $27 \%$ at the top of the core. The modern lake environment was established during this interval (Buso Jr. et al. 2013b).

\subsection{Phytolith assemblage record}

There is a great variability for phytoliths from the Lagoa do Macuco core. Many samples had very few or no phytoliths (e.g. samples between 194-144 cm, and 46 and $58 \mathrm{~cm}$ ) while others show good concentrations (e.g. sample $72-74 \mathrm{~cm}$ or $76-78 \mathrm{~cm}$ ), as illustrated in table 2 .
Table 2: Absolut phytolith number counted in three lines to each sample and phytolith indices.

\begin{tabular}{|l|c|c|c|c|}
\hline \multirow{2}{*}{ Depth (cm) } & \multirow{2}{*}{$\begin{array}{c}\text { Total } \\
\text { phytolith } \\
\text { counted in } \\
\text { three lines }\end{array}$} & \multicolumn{3}{|c|}{ Phytolith indices } \\
\cline { 3 - 5 } & 84 & 0 & 17 & 1 \\
\hline $22-24$ & 24 & 0 & 17 & 2 \\
\hline $24-26$ & 35 & 0 & 0 & 1 \\
\hline $26-28$ & 52 & 0 & 8 & 0 \\
\hline $44-46$ & 0 & 0 & 0 & 0 \\
\hline $46-48$ & 0 & 0 & 0 & 0 \\
\hline $54-56$ & 22 & 0 & 0 & 1 \\
\hline $56-58$ & 208 & 0 & 7 & 1 \\
\hline $58-60$ & 254 & 0 & 0 & 2 \\
\hline $72-74$ & 230 & 0 & 11 & 8 \\
\hline $76-78$ & 206 & 0 & 0 & 3 \\
\hline $78-80$ & 151 & 0 & 33 & 3 \\
\hline $84-86$ & 194 & 0 & 8 & 1 \\
\hline $90-92$ & 188 & 15 & 18 & 0 \\
\hline $100-102$ & 175 & 20 & 7 & 1 \\
\hline $110-112$ & 76 & 0 & 44 & 1 \\
\hline $118-120$ & 0 & 0 & 0 & 0 \\
\hline $130-132$ & 57 & 50 & 30 & 1 \\
\hline $142-144$ & 0 & 0 & 0 & 0 \\
\hline $152-154$ & 0 & 0 & 0 & 0 \\
\hline $162-164$ & 0 & 0 & 0 & 0 \\
\hline $176-178$ & 0 & 0 & 0 & 0 \\
\hline $184-186$ & 0 & 0 & 0 \\
\hline $192-194$ & 0 & & & \\
\hline & & 0 & 0 & 0 \\
\hline
\end{tabular}


Quaternary and Environmental Geosciences (2015) 06(1):41-50

Estudos ambientais sobre a vegetação e o clima no Holoceno

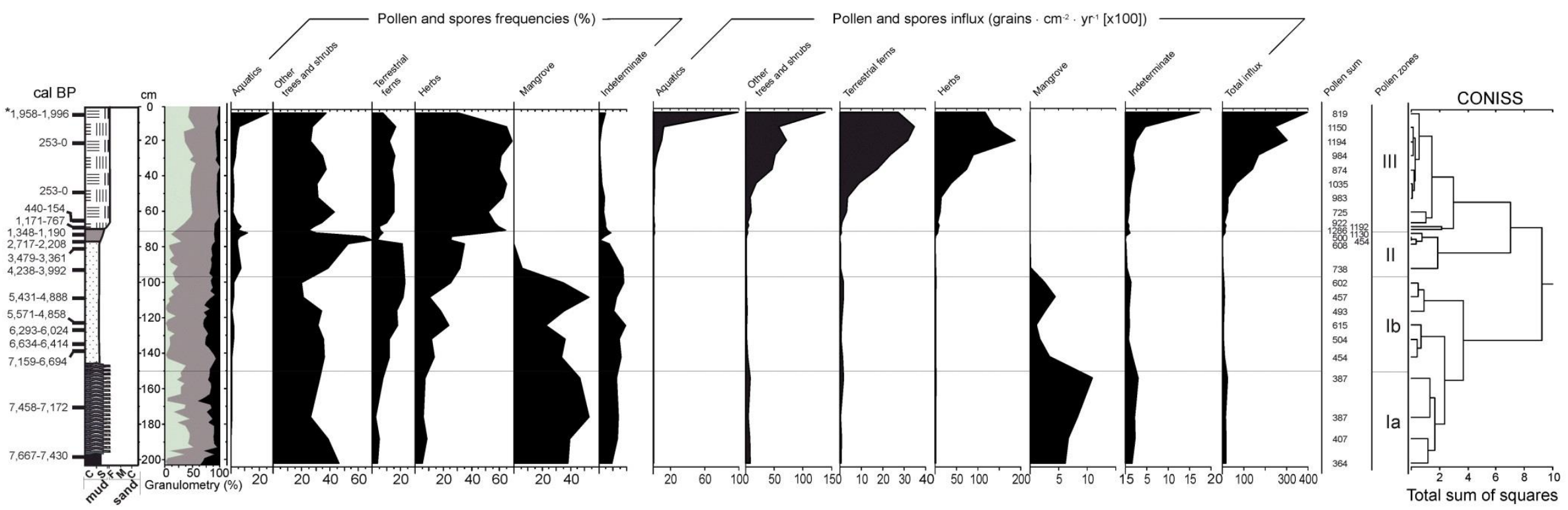

\begin{tabular}{|ll|}
\hline Granulometry & Lithology \\
$\square$ Sand & \\
Clit & \\
Clay & Meatgyttja \\
& Massive dark gray mud \\
& Darsive light gray mud \\
& Dark green mud
\end{tabular}

Figure 2: Calibrated ages, lithology; Pollen and spore percentage diagram, pollen and spore influx, cluster analysis, and pollen zones; 


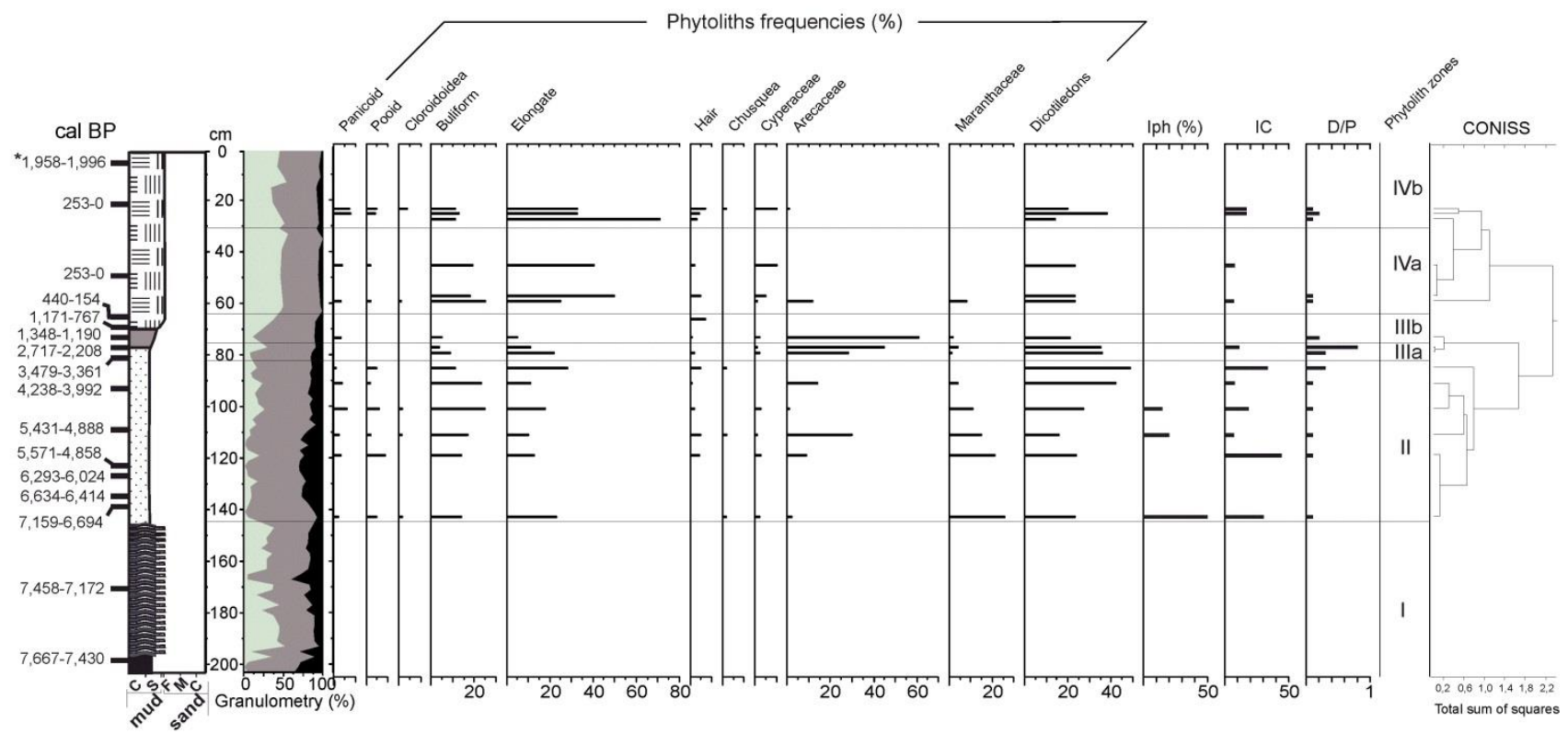

Granulometry
Sand
Clit
Llay
Lithology
Massive dark gray mud
Massive light gray mud
Dith greenish gray
Dark green mud

Figure 3: Calibrated ages, lithology; Phytolith percentage diagram, cluster analysis, phytolith indices and phytolith zones for the MAC-C core. 
The phytolith morphotypes identified are in figure 4 and the relative frequencies $(\%)$ are given in figure 3. The analysis of phytoliths shows a predominance of Monocotyledons plants (between $51 \%$ and $86 \%$ ), including Poaceae, Arecaceae and Cyperaceae. The bulliform (4\% and $25 \%)$ and elongate $(5 \%$ and $71 \%)$ forms from grasses are the most common morphotypes in all assemblages (figure 3)

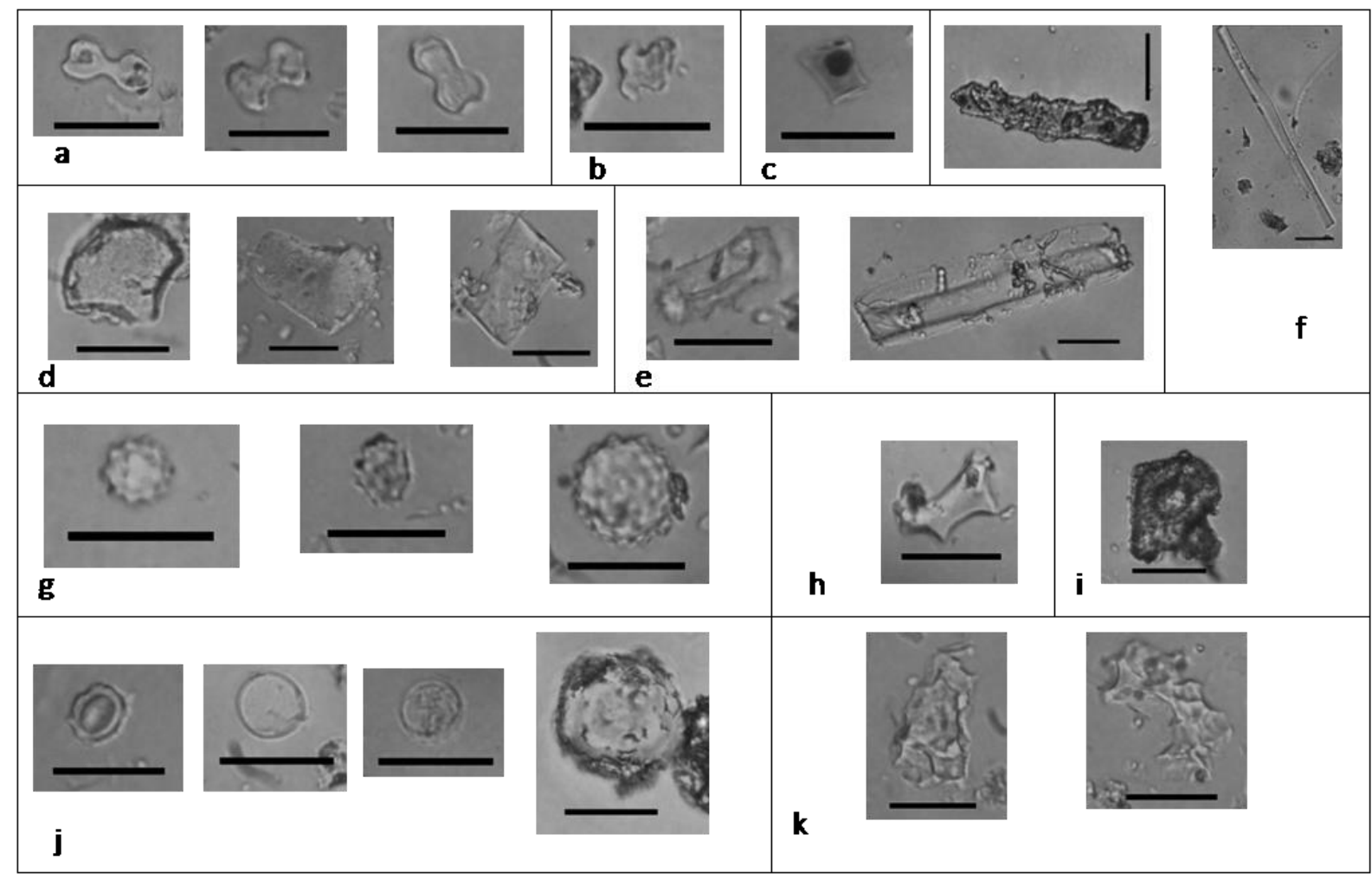

Figure 4: Microphotograph Phytoliths morphotypes: Poaceae: a) bilobates; b)cross; c) rondel; d) bulliform; e) trapeziform; f) elongate; Arecaceae: g) globular echinate; Chusquea: h) chusquea morphotype; Ciperaceae: i) ciperous morphotype; Eudicotiledoneae: j) globular ; Marantae: k)irregular

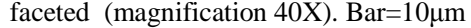

Panicoid short cells (C4) range between $3 \%$ and $8 \%$, and while the highest frequencies of Pooid (C3) phytoliths are from the base of the core, between 100 and $120 \mathrm{~cm}$ of depth. Chloridoids (C4 and C3) short cells were observed only at the top of the sequence $(22-$ $24 \mathrm{~cm}$ ), representing less than $4 \%$ of the assemblage (figure 3). Frequencies of Chusquea (Poaceae, Bambuseae) phytoliths are always below $2 \%$ and the morphotype is found only in samples at $22-24 \mathrm{~cm}, 84-$ $86 \mathrm{~cm}$ and $110-112 \mathrm{~cm}$ of dept. Cyperaceae phytoliths were between $1 \%$ and $10 \%$ of the total assemblages but their presence is observed only between 144-142, 12058 and 46-22 $\mathrm{cm}$ (figure 3 ).

Tree phytoliths (Eudicotiledoneae) frequencies varies along the deposit, they increase between 103 and 63 $\mathrm{cm}$ to then diminish at $30 \mathrm{~cm}$ and increase again at 23 $\mathrm{cm}$ (table 1). The frequency of the Arecaceae phytoliths (globular echinate) is higher (28\%-61\%) between $58-120 \mathrm{~cm}$ of depth. Between 72 and $78 \mathrm{~cm}$ of depth, it was also observed an abrupt increase in the Arecaceae phytoliths.

The cluster analysis of the phytolith assemblages shows four phytolith zones (figure 3):

Phytolith Zone I, 7700-7100 cal yr BP (204-142 cm): No phytoliths were observed in these samples. The pollen analysis indicates a mangrove environment and because these species do not seem to have silica deposition, it could explain the absence of phytoliths.
Phytolith Zone II, 7100-3400 cal yr BP (142-82 cm): The phytolith assemblages are dominated by monocotiledoneae phytoliths (53-71\%) with Maranthaceae phytoliths increasing with depth. According to phytolith indices this zone is a temperate interval, colder (IC 7\% - 30\%) but moister (Iph 50\% $15 \%)$ than Zones III and IV. These results corroborate the hypothesis of a more humid interval between 70004000 cal BP (Buso Jr. et al. 2013a), in which the influence of both polar air masses and the summer monsoon system contributed to high humidity levels at Linhares during the whole year. Nonetheless, IC and Iph indices indicate that this humid interval may have extended only up to about 3400 cal yr BP.

The D/P index (between 0.1 and 0.3) shows a reduced tree cover during the interval between 7000 and 3400 cal. BP together with relatively higher values of Cyperaceae and Pooid (C3 - Poideae) that should represent more hydromorphic vegetation. The phytolith evidence seems to show a displacement of the arboreal vegetation to the more elevated margins of Barra Seca Valley due to the higher relative sea level, as evidenced by the pollen dataset (Buso Jr. et al. 2013b).

Phytolith Zone III, 3400-400 cal yr BP $(82-64 \mathrm{~cm})$ is subdivided into two:

Sub-zone IIIa: The samples between 82 and $76 \mathrm{~cm}$ have phytolith assemblages dominated by trees (Eudicotiledoneae) and tree palms (Arecaceae). The 
bulliform and elongate morphotypes have low frequencies; however, the constant presence of bulliform can be interpreted as the presence of moisture without water deficit.

Sub-zone IIIb: The samples obtained between $76 \mathrm{~cm}$ and $60 \mathrm{~cm}$ have phytolith assemblages dominated by trees (Eudicotiledoneae) and palms (Arecaceae), with few other Monocotiledoneae. The phytolith indices highlight a period with the highest presence of arboreal vegetation probably adapted to little temperature variability and with moister conditions Palms constitute part of the arboreal vegetation, similarly to what observed today in the tropical rainforest. The massive dark gray mud sediment and the higher sedimentation rate (see Buso Jr. 2010) also suggest that the vegetation was denser than in the other phytolith zones.

Phytolith Zone IV, 400 cal yr BP to modern (64-00 $\mathrm{cm})$ is subdivided into two:

Sub-zone IVa (from $440 \mathrm{Cal}$ yrs B.P to ca. $253 \mathrm{cal} \mathrm{yr}$ $\mathrm{BP})$ : There is a decrease in the Eudicotiledoneae (tree) phytoliths frequencies (5-15\%) while the Arecaceae morphotypes are absent. This data confirms the palynological evidence of stabilization of the forest in the surrounding of the lake and the formation of an herbaceous layer composed by Panicoid high grasses and Cyperaceae (sedges).

Sub-zone IVb (from ca. 253 cal yr BP to modern): The overall tree cover seems to be slightly reducing (D/P value close to 0.2 ) but there is an increase in specific taxa such as Chusquea (2\%) and Cyperaceae $(10 \%)$, in comparison with the subjacent sub-zone. In this zone Poaceae are more frequent, with an increase in C4 grasses short cells (Panicoid and Chloridoid) and a slight decrease in bulliforms. These data seems to disagree with the $\delta^{13} \mathrm{C}$ values, which indicate that the organic matter was derived mainly from C3 plants (Buso Jr. et al. 2013a) but it might be due to the diverse input basin for the two different proxies (more local for the phytoliths and more regional for the pollen). The phytolith indexes indicate drier and warmer local environmental conditions (Iph) and arboreal vegetation $(\mathrm{D} / \mathrm{P})$.

\section{Conclusions}

The analysis of phytoliths was a good tool to complement the pollen data in order to provide additional information, specifically on issues of moisture and temperature. The two plant proxies tend to be in good agreement, showing the dynamics of the arboreal and non-arboreal vegetation in respect to the Mid-Holocene humid period and the changes in the sea level.

The phytolith dataset contributed with details the changes in the local vegetation structure, also highlighting the pulses in the $\mathrm{C} 3$ and $\mathrm{C} 4$ grass composition.

\section{Acknowledgments}

The authors express their gratitude to Vale and Sooretama Nature Reserves (Linhares, ES, Brasil) for the field support. This work received financial support by the São Paulo Foundation for Research (FAPESP), grant 2011/00995-7, and CNPq (Universal), grant 470210/2012-5.

\section{References}

Alexandre A., Meunier J-D., Colin F., Koud J-M. 1997a. Plant impact on the biogeochemical cycle of silicon and related weathering processes. Geochimica et Cosmochimica Acta, 61(3):677-682.

Alexandre A., Meunier J.-D., Lczine A-M., Vincens A., Schwartz, D. A. 1997b. Phytoliths: indicators of grassland dynamics during the late Holocene in intertropical Africa. Palaeogeography, Palaeoclimatology, Palaeoecology, 136:213-229.

Alexandre A., Meunier J-D., Mariotti A., Soubies F. 1999. Late Holocene phytolith and carbon-isotope record from a latosol at Salitre, South-Central Brazil. Quaternary Research, 51:187-194.

Angulo R.J., Lessa G.C., Souza M.C. 2006. A critical review of midto late-Holocene sea-level fluctuations on the eastern Brazilian coastline. Quaternary Science Reviews, 25:486-506.

Arai M., 2006. A grande elevação eustática do Mioceno e sua influência na origem do Grupo Barreiras. Geologia USP Série Científica, 6 (2):1-6.

Barboni D., Bonnefille R., Alexandre, A., Meunier J. D. 1999. Phytoliths as paleoenvironmental indicators, West Side Middle Awash Valley, Ethiopia. Palaeogeography, Palaeoclimatology, Palaeoecology, 152:87-100.

Barboni D., Bremond L., Bonnefille R., 2007. Comparative study of modern phytolith assemblages from inter-tropical Africa. Palaeogeography, Palaeoclimatology, Palaeoecology 246:454470 .

Bartlett A.S., Barghoorn E.S. 1973. Phytogeographic history of the Isthmus of Panama during the past 12,000 Years (A history of vegetation, climate and sea-level change). In: GRAHAM A. (eds) Vegetation and vegetational history of northern Latin America. Elsevier Scientific, New York, 203-299p.

Birks H.H., Birks H.J.B. 2006. Multi-proxy studies in palaeolimnology. Vegetation History and Archaeolbotany, 15:235-251.

Borba-Roschel M., Alexandre A., Varajão A.F.D.C., Meunier J.D., Varajão C.A.C., Colin F. 2006. Phytoliths as indicators of pedogenesis and paleoenvironmental changes in the Brazilian cerrado. Journal of Geochemical Exploration, 88:172-176.

Bremond L., Alexandre A., Hély C., Guiot J. 2005. A phytolith index as a proxy of tree cover density in tropical areas: calibration with Leaf Area Index along a forest-savanna transect in southern Cameroon. Global and Planetary Change, 45(4):277293.

Buso Junior A.A. 2010. Dinâmica ambiental holocênica (vegetação, clima e nível relativo marinho) baseada em estudos interdisciplinares de alta resolução, no litoral norte do estado do Espírito Santo. Dissertação de Mestrado. Pós-graduação em Ciências, Centro de Energia Nuclear na Agricultura, Universidade de São Paulo, 190p.

Buso Jr. A.A., Pessenda L.C.R., Giannini P.C.F., De Oliveira P.E., Cohen M.C.L., Volkmer-Ribeiro C., Oliveira S.M.B., Rossetti D. F., Lorente F. L., Borotti Filho M. A., Schiavo J. A., Bendassolli J. A., França M. C., Guimarães J. T. F., Siqueira G. S. 2013a. Late Pleistocene and Holocene vegetation, climate dynamics, and Amazonian taxa in the Atlantic Forest. 55(23):1747-1762.

Buso Jr A.A., Pessenda L.C.R., De Oliveira P.E., Giannini P.C.F., Cohen M.C.L., Volkmer-Ribeiro C., Oliveira S.M.B., Favaro D.I.T., Rossetti D.F., Lorente F.L., Borotti Filho M.A., Schiavo J.A., Bendassolli J.A., França M.C., Guimarães J.T.F. 2013b. From an estuary to a freshwater lake: a paleo-estuary evolution in the context of Holocene sea-level fluctuations, SE Brazil. Radiocarbon, 55(2-3):1735-1746. 
Calegari M.R., Madella M., Vidal-Torrado P., Pessenda L.C.R., Marques F.A. 2013a. Combining phytolith and $\delta^{13} \mathrm{C}$ matter in Holocene paleoenvironmental studies of tropical soils: an example of an Oxisol in Brazil. Quaternary International, 287:47-55.

Calegari M.R., Madella M., Vidal-Torrado P., Ottero J. L., Macias F., Osterrieth M. 2013b. Opal phytolith extraction in oxisols.. Quaternary International, 287:56-62.

Carnelli A. 2002. Long term dynamics of the vegetation at the subalpine-alpine ecocline during the Holocene: comparative study in the Aletsch region, Val d'Arpette, and Furka Pass (Valai, Switzerland). Terre \& Environnement, Suisse, 349p.

Coe H.H.G., Alexandre A., Carvalho C.N., Santos G.M., Silva A.S., Sousa L.O.F., Lepsch I.F. 2013. Changes in Holocene tree cover density in Cabo Frio (Rio de Janeiro, Brazil): Evidence from soil phytolith assemblages. Quaternary International, 287:63-72.

Colinvaux P., De Oliveira P.E., Patiño J.E.M. 1999. Amazon pollen manual and atlas. Manual e atlas palinológico da Amazônia. Harwood Academic Publishers, Amsterdam. 322p.

Curtis J., Wendler G., Stone R., Dutton E. 1998. Precipitation decrease in the western Arctic, with special emphasis on Barrow and Barter Island. Alaska International Journal of Climatology, 18:1687-1707.

Davis M. B., Deevy Jr. E. S., 1964. Pollen accumulation rates: estimates from Late Glacial sediment of Rogers Lake. Science, 145: 1293-1295

Diester-Haas L., Schrader H.J., Thiede J. 1973. Sedimentological and paleoclimatological investigations of two pelagic ooze cores off Cape Barbas, North-West Africa. Meteor Forsch-Ergebnisse, 16:19-66.

Dominguez J.M.L. 2009. The coastal zone of Brazil. In: Dillenburg S.R., Hesp P.A. (eds.). Geology and geomorphology of Holocene coastal barriers of Brazil. Springer-Verlag, Berlin, 17$46 \mathrm{p}$.

Grimm E. C. 1987. CONISS: A Fortran 77 program for stratigraphycally constrained cluster analysis by the method of incremental sum of squares. Computers \& Geosciences, 13(1):13-35.

Grimm E. C. 1992. Tilia and Tilia-Graph: pollen spreadsheet and graphics programs. Abstracts 8th International Palynological Congress. Aix-en-Provence: 56.

Kondo R., Iwasa Y. 1981. Biogenic opals of humic yellow latosols and yellow latosols in the Amazon region. Research Bulletin Obihiro University, 12:231-239.

Livingstone D.A. 1955. A lightweight piston sampler for lake deposits. Ecology 36(1):137-139.

Lorscheitter M. L., Ashraf A.R., Windisch P.G., Mosbrugger V. 1999. Pteridophyte spores of Rio Grande do Sul flora, Brazil. Part II. Palaeontographica, 251:7-235.

Mccormac F.G., Bayliss A., Baillie M.G.L., Brown D.M. 2004. Radiocarbon calibration in the Anglo-Saxon period: AD 495725. Radiocarbon, 46(3):1123-5.

Madella M., Powers-Jones A. H., Jones M. K. 1998. A Simple Method of Extraction of Opal Phytoliths from Sediments Using a Non-Toxic Heavy Liquid. Journal of Archeological Science, 25:801-803.

Madella M., Alexandre A., Ball T. 2005. International Code for Phytolith Nomenclature 1.0. Annals of Botany, 96(2):253-260.

Marchant R., Almeida L., Behling H., Berrio J.C., Bush M., Cleef A., Duivenvoorden J., Kappelle M., De Oliveira P., Oliveira-Filho A.T., Lozano-García S., Hooghiemstra H., Ledru M-P., LudlowWiechers B., Markgraf V., Mancini V., Paez M., Prieto A., Rangel O., Salgado-Labouriau M.L. 2002. Distribution and ecology of parent taxa of pollen lodged within the Latin American Pollen Database. Review of Palaeobotany and Palynology, 121:1-75.

Martin L., Dominguez J.M.L., Bittencourt A.C.S.P. 2003. Fluctuating Holocene sea levels in eastern and southeastern Brazil: evidence from multiple fossil and geometric indicators. Journal of Coastal Research, 19(1):101-124.

Murray-Wallace C.V. 2007. Eustatic sea-level changes since the Last Glaciation. In, Elias, S. (Ed). Encyclopedia of Quaternary Science, 4:3034-3043.

Mworia-Maitima J. 1997. Prehistoric fires and land cover change in western Kenya: Evidences from pollen, charcoal, grass cuticles, and grass phytoliths. The Holocene, 7:409-417.
Orth C.K. 1922. A scale of grade and class terms for clastic sediments. Journal of Geology, 30(5):377-392.

Osterrieth M., Madella M., Zurro D., Alvarez M.F. 2009. Taphonomical aspects of silica phytoliths in the loess sediments of the Argentinean Pampas. Quaternary International, 193:70-79.

Peixoto A.L., Gentry A. 1990. Diversidade e composição florística da mata de tabuleiros na Reserva Florestal de Linhares (Espírito Santo, Brasil). Revista Brasileira de Botânica. 13(1):19-25.

Penny D., Kealhofer L. 2005. Microfossil evidence of land use intensification in Northern Thailand. Journal of Archaeological Science, 32:69-82.

Pessenda, L. C. R.; Oliveira, P. E. De; Mofatto, M.; Medeiros, V. B. De; Garcia, R. J. F.; Aravena, R.; Bendassoli, J. A.; Leite, A. Z.; Saad, A. R., Etchebehere, M. L., 2009. The evolution of a tropical rainforest/grassland mosaic in Southeastern Brazil since $28,00014 \mathrm{C}$ yr BP based on carbon isotopes and pollen records. Quaternary Research 71, 437-452.

Piperno D. 1993. Phytolith and charcoal records from deep lake cores in the American tropics. In: pearsall d.m., piperno d.r. (eds.) Current Research in Phytolith Analysis: Applications in Archaeology and Paleoecology. Philadelphia, MASCA University Museum of Archaeology and Anthropology, 58-71p.

Piperno D.R., Pearsall D.M. 1998. The origins of agriculture in the lowland Neotropics. San Diego: Academic Press. 400 p

Piperno D.R., Jones J.G. 2003. Paleoecological and archaeological implications of a Late Pleistocene/Early Holocene record of vegetation and climate from the Pacific coastal plain of Panama. Quaternary Research, 59:79-87.

Piperno D. R. 2006. Phytoliths: A Comprehensive Guide for Archaeologists and Paleoecologists. Lanham. AltaMira Press, 238p.

Reimer P.J., Baillie M.G.L., Bard, E., Bayliss, A., Beck, J.W., Bertrand, C., Blackwell, P.G., Buck, C.E., Burr, G., Cutler, K.B., Damon, P.E., Edwards, R.L., Fairbanks, R.G., Friedrich, M., Guilderson, T.P., Hughen, K.A., Kromer, B., McCormac, F.G., Manning, S., Ramsey,C.B, Reimer,R.W., Remmele, S., Southon, J.R., Stuiver, M., Talamo, S. Taylor, F.W., van der Plicht, J., Weyhenmeyer, C.E., 2004. INTCAL04 terrestrial radiocarbon age calibration, 0-26 cal kyr BP. Radiocarbon 46, 1029-1058.

Runge F. 1999. The opal phytolith inventory of soil in central Africa - quantities, shapes, classification, and spectra. Review of Palaeobotany and Palynology, 107:23-53.

Souza V.C., Lorenzi H. 2008. Botânica Sistemática. Guia ilustrado para identificação das famílias de Angiospermas da flora brasileira, baseado em APG II. Ed. 2. Instituto Plantarum de Estudos da Flora Ltda, Nova Odessa. 674p.

Tieszen L. L., Hein D., Qvortrup S., Troughton J., Imbamba S. 1979. Use of de ${ }^{13} \mathrm{C}$ values to determine vegetation selectivity in East African herbivores. Oecologia, 37:351-359.

Thorn V. 2004. Phytolith evidence for C4-dominated grassland throughout the Holocene at Long Pocket, northeast Queensland, Australia. Quaternary Research, 61: 168-180.

Twiss C., Suess E., Smith R. M. 1969. Morphological classification of grass phytoliths. Soil Science Society of America Proceedings, 33:109-115.

Twiss P.C., 1987. Grass opal phytoliths as climatic indicators of the Great Plains Pleistocene. In: Johnson,W.C. (Ed.), Quaternary Environments of Kansas. Kansas Geological Survey Guidebook, 5:179-188

Twiss P. C. 1992. Predicted world distribution of C3 and C4 grass phytoliths. In: Rapp G., Mulholland S.C. (eds.). Phytolith Systematics. New York, Plenum Press, 113-128p.

Wentworth C K. 1922. A scale of grade and class terms for clastic sediments. Journal of Geology, 30:377-392.

Recebido 06 de maio de 2014 Aceito 17 de abril de 2015 